Available online at: http://proceeding.rsfpress.com/index.php/pss/index

LPPM UPN “Veteran" Yogyakarta Conference Series

Proceeding on Political and Social Science (PSS)

Volume 1 Number 1 (2020): 166-173

\title{
The Effect of Digital Marketing Capability Against Marketing Performance with Innovation as mediation (Study on Batik SMEs during the Covid-19 Pandemic)
}

\author{
Humam Santosa Utomo, Susanta \\ Universitas Pembangunan Nasional Veteran Yogyakarta \\ E-mail address humam.santosautomo@upnyk.ac.id; E-mail address susanta@upnyk.ac.id
}

\begin{abstract}
There The Covid-19 pandemic has an impact on SMEs in Bantul, Yogyakarta. During a pandemic, SMEs rely on digital marketing to access consumers. This study aims to examine the effect of digital marketing capabilities on innovation capabilities, the influence of digital marketing capabilities on marketing performance, and innovation capabilities on marketing performance. The research was conducted on SMEs that produce batik at the Giriloyo batik center and the Wijirejo batik center, Bantul, Yogyakarta. Respondents of this study believe 81 SMEs were selected by cluster sampling. The research instrument used a questionnaire and the data were processed using SPSS and WarpPLS. The results of this study found that digital marketing capabilities have a significant effect on innovation capabilities, digital marketing capabilities have a significant effect on marketing performance, and innovation capabilities have a significant effect on marketing performance. The results of this study are useful for SMEs to improve their digital marketing capabilities and the government to participate in providing technical training related to online sales.
\end{abstract}

Keywords: Digital Marketing Capability, Innovation, Marketing Performance, Pandemic Covid-19

\section{INTRODUCTION}

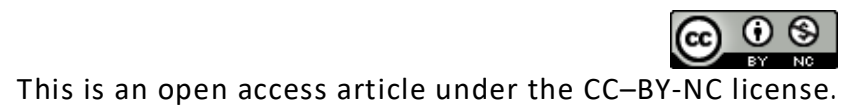

SMEs engaged in batik production experienced the impact of the Covid-19 disaster, including the Giriloyo and Wijirejo batik centers in Bantul, Yogyakarta. Based on the results of observations and interviews with Batik entrepreneur in the area on April 15-16 2020, they felt the impact of the corona disaster, even though not all SMEs had a negative impact. The impacts experienced vary, ranging from decreased sales, inefficient production due to rising raw material prices, delays in product distribution, and several other impacts that resulted in decreased sales. Many factors affect the performance of SMEs, including internal factors and external factors. Internal factors such as innovation, digital marketing capability, 
entrepreneurship, and relation capability. External factors that are felt are uncertain environmental conditions.

This study aims to determine the effect of Digital Marketing Capability on Innovation, Innovation on Marketing Performance, and Digital Marketing Capability on Marketing Performance. This research was conducted during the Covid-19 pandemic so it is unique compared to previous studies. This research is important to do to describe the internal factors of entrepreneurs that affect the performance of SMEs.

\section{LITERATURE REVIEW}

\section{II.1. Resource-Based View}

The relationship between concepts in this study refers to the Resource-Based View (RBV). RBV analyzes and interprets organizational resources to understand how the organization achieves a sustainable competitive advantage to achieve the specified performance. RBV focuses on the concept of company attributes that are difficult to imitate as a source of superior performance and competitive advantage (Barney, 1991; Hamel and Prahalad, 1996). Resources that cannot be easily transferred or purchased, which require a long learning curve or major changes in organizational climate and culture, are more likely to be unique to the organization and, therefore, more difficult for competitors to imitate. According to Conner (1991), the variance in performance between firms depends on input ownership and unique abilities. The ability to apply digital marketing and entrepreneurial orientation creates unique products in the form of innovation so that it becomes a company advantage that has implications for performance. External factors also have an impact on company excellence so that it also has implications for performance. In the context of this research, the external environment is in the form of environmental uncertainty which is expected to hinder performance.

\section{II.2. Digital Marketing Capability}

Digital marketing capability in this study refers to the company's ability to utilize digital media as part of a marketing strategy, especially market-oriented products, distribution networks, and promotions. Ellonen (2012) defines Digital Marketing Capability as The ability of businesses to market their products and services by using digital technology in obtaining customers, promoting brands, retaining customers, and increasing sales. Digital marketing has several advantages over conventional marketing, including coverage. Digital marketing can expand the market with online-based technology so that it is more efficient. Besides that, digital marketing also makes it easier for companies to find creative ideas so that companies can come up with new, innovative products. Wardaya et al. (2019) reveal the dimensions of Digital Marketing Capability include Customer Information, Customer Needs, Customer Relations, and Customer Communication.

\section{II.3. Innovation Capability}

Innovation capability is the ability to develop new products according to market demand (Adler \& Shenbar, 1990). Innovation is an important organizational capability because the 
success of new products is a growth engine that has an impact on increasing sales, profits, and the strength of competition (Battor \& Battor, 2010; Sivadas \& Dwyer, 2000). Innovation includes the process, product, and organization of new ideas (Hult et al., 2004). Thornhill (2006) describes the steps of innovation starting from finding ideas, developing findings, introducing new products and services in the market (Thornhill, 2006).

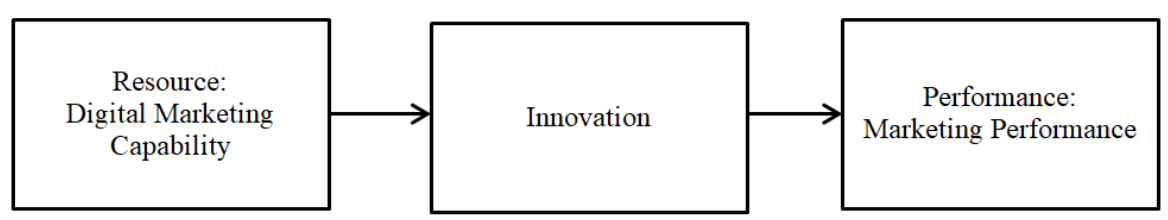

Figure 1. RBV-Based Research Conceptual Model

\section{II.3. Digital Marketing Capability, Innovation, and Marketing Performance}

The development of marketing, financial, production, and human resource capabilities is an important aspect of creating innovation in small or medium-sized companies (Baldwin, 1995). Marketing capability is correlated with innovation (Weerawardena, 2003). Marketing ability is considered important in driving company performance (Day, 1994; Morgan et al., 2009; O'Cass \& Ngo, 2011). Wisdom (2015) and Onyango (2016) found that digital marketing has a positive effect on performance. Binter (2019) also revealed that digital marketing drives sales success. Based on this description, the following hypothesis is formulated:

H1. Digital Marketing Capability has a significant effect on Innovation.

H2. Digital Marketing Capability has a significant effect on Marketing Performance.

\section{II.4. Innovation and Marketing Performance}

A study conducted by Tsai and Tsai (2010) concluded that innovation significantly and positively affects performance. A study conducted by Battor and Battor (2010) found a strong relationship between innovation ability and performance. Sulistyo and Siyamtinah (2016) concluded that SME innovation has a significant positive effect on SME performance. In the context of this study, the performance dimensions of SMEs are measured from a marketing perspective.

H3. Innovation has a significant effect on Marketing Performance.

\section{RESEARCH METHODOLOGY}

This type of research is explanatory research, namely research that explains the causal relationship (cause and effect) between variables through hypothesis testing as well as explanations. The approach used in analyzing this research is quantitative (Kerlinger, 2003). This research was conducted in the district of Bantul, Yogyakarta, Indonesia. The population in this study were the batik SMEs in the Giriloyo batik center and the Wijirejo batik center. The population of this research is 810 Batik UKM. The research sample consisted of 81 respondents who were selected by cluster sampling technique. The research variables consist of 1) Digital Marketing Capability (X), Innovation Capability (Y1), and Marketing 
Performance (Y2). The variable digital marketing capability is measured according to Wardaya et al. (2019), the innovation capability variable based on Thornhill (2006), and the Marketing Performance variable adapting Battor and Battor (2010) and Sulistyo \& Siyamtinah (2016). Data were collected using a questionnaire and each item was measured by a Likert scale, which was graded from strongly disagree (1) to strongly agree (5). The validity and reliability of the questionnaire were tested on 30 respondents before being used for all respondents. Data were analyzed using WarpPLS 6.0 (Kock, 2015) to determine the influence between variables in the structural model.

\section{FINDING AND DISCUSSION}

\section{1. Validity and reliability of the instrument}

The research instrument testing was carried out on 30 Batik SMEs in Giriloyo and Wijirejo batik centers. The results of the research instrument test show that the correlation coefficient value of each item with a total item $\geq 0.3$ so it can be stated that the instrument produces valid data (Sekaran, 2011). The test results also show that the Cronbach's Alpha coefficient is $\geq 0.6$, so it can be stated that the instrument is reliable (Malhotra, 2010).

Table 1: Result of instrument validity test

\begin{tabular}{|c|c|c|c|}
\hline Variable & Indicator & $\begin{array}{l}\text { Correlation } \\
\text { Coefficient }\end{array}$ & $\begin{array}{l}\text { Cronbach's } \\
\alpha\end{array}$ \\
\hline \multirow{4}{*}{$\begin{array}{l}\text { Digital } \\
\text { Marketing } \\
\text { Capability (X) }\end{array}$} & Customer Information & 0.454 & \multirow[t]{4}{*}{0.777} \\
\hline & Customer Needs & 0.662 & \\
\hline & Customer Relations & 0.768 & \\
\hline & Customer Communication & 0.562 & \\
\hline \multirow[t]{2}{*}{$\begin{array}{l}\text { Innovation } \\
\text { Capability (Y1) }\end{array}$} & $\begin{array}{l}\text { Ability to create new } \\
\text { products innovation }\end{array}$ & 0.745 & \multirow[t]{2}{*}{0.853} \\
\hline & $\begin{array}{l}\begin{array}{l}\text { Ability to create } \\
\text { services }\end{array} \\
\text { new }\end{array}$ & 0.735 & \\
\hline \multirow{5}{*}{$\begin{array}{l}\text { Marketing } \\
\text { Performance } \\
\text { (Y2) }\end{array}$} & Increased market coverage & 0.885 & \multirow[t]{5}{*}{0.893} \\
\hline & $\begin{array}{l}\text { Addition of new market } \\
\text { segments }\end{array}$ & 0.866 & \\
\hline & $\begin{array}{l}\text { Increase in the total number } \\
\text { of subscribers }\end{array}$ & 0.894 & \\
\hline & $\begin{array}{l}\text { An increase in the number of } \\
\text { new customers }\end{array}$ & 0.842 & \\
\hline & Sales increase & 0.844 & \\
\hline
\end{tabular}

Table 2. Characteristics of the sample ( $\%$ of respondents, $n=81$ )

\begin{tabular}{lll}
\hline Gender & Male & 76.54 \\
\cline { 2 - 3 } & Female & 23.46 \\
\hline
\end{tabular}


The Effect of Digital Marketing Capability Against Marketing Performance with Innovation as mediation (Study on Batik SMEs during the Covid-19 Pandemic)

Humam Santosa Utomo, Susanta

\begin{tabular}{lll}
\hline \multirow{2}{*}{ Entrepreneur age } & & \\
\cline { 2 - 3 } & $18-25$ years & 13.58 \\
\cline { 2 - 3 } & $26-45$ years & 60.46 \\
\hline Firm age & $3-6$ years & 25.96 \\
\cline { 2 - 3 } & $7-10$ years & 25.93 \\
\cline { 2 - 3 } & $>10$ years & 28.40 \\
\hline Marital status & Single & 45.67 \\
\cline { 2 - 3 } & Married & 16.05 \\
\hline
\end{tabular}

\section{IV.2.Profile of Respondents}

Table 2 shows that the majority of respondents are male (76.54\%), most of the entrepreneurs are in the $26-45$ age category $(60.46 \%)$. Most of the companies were $>10$ years old $(45.67 \%)$ and most of the respondents were married $(83.95 \%)$.

\section{IV.3. Final Structural Model}

The measurement results of the fit and quality indices model show that all items are by the requirements in the WarpPLS (Kock, 2015).

Table 3. Hypothesis testing results

\begin{tabular}{llllll}
\hline Relations between variables & $\begin{array}{l}\text { Coefficien } \\
\mathbf{t}\end{array}$ & $\boldsymbol{p}$-value & $\begin{array}{l}\text { Descriptio } \\
\mathbf{n}\end{array}$ & $\begin{array}{l}\text { Hypothesis } \\
\text { Decision }\end{array}$ \\
\hline $\begin{array}{l}\text { Digital } \\
\text { Marketing }\end{array}$ & Innovation & 0.663 & $<0.000$ & Significant & Accepted \\
Capability & Capability & & & & \\
\hline $\begin{array}{l}\text { Digital } \\
\text { Marketing }\end{array}$ & Marketing & 0.325 & $<0.000$ & Significant & Accepted \\
Capability & Performance & & & & \\
\hline $\begin{array}{l}\text { Innovation } \\
\text { Capability }\end{array}$ & $\begin{array}{l}\text { Marketing } \\
\text { Performance }\end{array}$ & 0.552 & $<0.000$ & Significant & Accepted \\
\hline
\end{tabular}

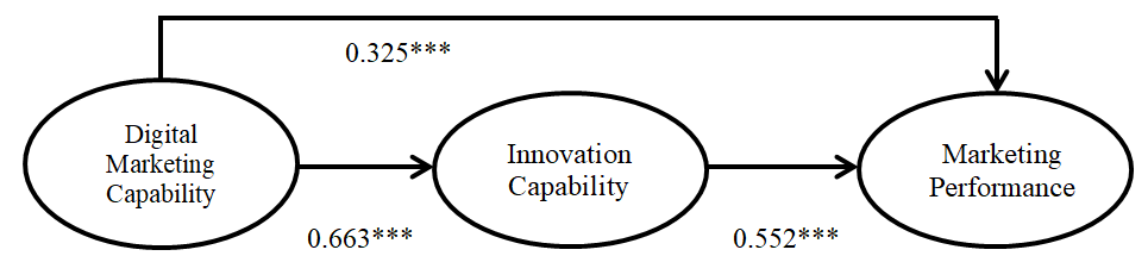

Figure 2. Final Structural Model

\section{CONCLUSION AND FURTHER RESEARCH}

\section{V.1. The Influence of Digital Marketing Capability on Innovation}

The results of this study reveal that innovation capability is influenced by digital marketing capability. The results of this study strengthen the RBV argument (Barney, 1991; Hamel and 
Prahalad, 1996). RBV focuses on the concept of company attributes that are difficult to imitate as a source of superior performance and competitive advantage. One of the advantages the company has is innovation. These results support the research of Baldwin (1995). These results also support the study of Weerawardena (2003) which concluded that there is a very strong influence of marketing capabilities on innovation.

\section{V.2. The Effect of Digital Marketing Capability on Marketing Performance}

The results of this study found that digital marketing capability affects marketing performance. The results of this study reinforce RBV (Barney, 1991; Hamel and Prahalad, 1996) which states that company resources are a source of company performance. The results of this study are also consistent with previous studies (Day, 1994; Morgan et al., 2009; O'Cass \& Ngo, 2011; Wisdom, 2015; Onyango, 2016; Binter, 2019). Marketing ability is considered important in driving company performance. Digital marketing capability has a positive effect on sales success.

\section{V.3. The Influence of Innovation on Marketing Performance}

These results indicate that innovation capability affects marketing performance. By RBV (Barney, 1991; Hamel and Prahalad, 1996), innovation capability is one of the company's resources that can create unique service goods that have implications for company performance. The results of this study support the research of Tsai and Tsai (2010). Battor and Battor (2010) have also revealed a strong relationship between innovation capabilities and performance. Sulistyo and Siyamtinah (2016) also found that the performance of SMEs is determined by the company's innovation ability.

This study has several limitations. First, the research was conducted only on batik SMEs. Second, this study is cross-sectional. Further research is proposed to examine more broadly other aspects that influence innovation during the Covid-19 pandemic. Further research is also expected to expand the research location and research object. Future studies can also compare the results of research during this pandemic with studies during normal times.

\section{REFERENCES}

Adler, P. S., \& Shenbar, A. 1990. Adapting your technological base: The organizational challenge. Sloan Management Review, 25, 25-37.

Baldwin, J. 1995. Innovation: The key to success in small firms. Statistics Canada Working Paper, 76. Retrieved on December 22nd, 2014.

Barney, J. B. 1991. Firm resources and sustained competitive advantage. Journal of Management, 17(1), 99-120.

Battor, M., \& Battor, M. 2010. The impact of customer relationship management capability on innovation and performance. Journal of Marketing Management, 26(9-10), 842-857.

Binder, U. 2019. Influence of Online Marketing Strategies on the Sales Success of B2B Companies. Thesis. Vienna University

Bieler, L. 2005. The Moderating Effect of Environmental Uncertainty on New Product Development and Time Efficiency. Journal of Product Innovation Management (22:3), pp 267-284. 
Conner, K. 1991. Historical comparison of resource-based theory and five schools of thought within industrial organization economics: Do we have a new theory of the firm?. Journal of Management, 17(1), pp.121-154

Day, G. S. 1994. The capabilities of market-driven organizations, Journal of Marketing, 58(4), pp. 37-52.

Engage, C., and Hoffmann, V. H. 2009. Effects of regulatory uncertainty on corporate strategy-an analysis of firms' responses to uncertainty about post-Kyoto policy, Environmental Science \& Policy (12:7), pp 766-777.

Fredrickson, J. W., and Mitchell, T. R. 1984. Strategic decision processes: comprehensiveness and performance in an industry with an unstable environment, Academy of Management Journal (27:2), pp 399-423.

Hamel, G., and Prahalad, C. 1996. Competing for the Future, Harvard Business School Press, Paperback edition, Boston (Massachusetts).

Hult, G. T., Hurley, R., \& Knight, G. 2004. Innovativeness: Its antecedents and impact on business performance. Industrial Marketing Management, 33(5),429e438.

Johnson, A. M., and Lederer, A. L. 2005. The effect of communication frequency and channel richness on the convergence between chief executive and chief information officers, Journal of Management Information Systems (22:2), pp 227-252.

Johnston, M., Gilmore, A., and Carson, D. 2008. Dealing with environmental uncertainty: The value of scenario planning for small to medium-sized enterprises (SMEs), European Journal of Marketing (42:11/12), pp 1170-1178.

Kerlinger, F.N. 2003. Asas-asas Penelitian Behavioral (3th ed). Yogyakarta: Gadjah Mada University Press

Kock, N. 2015. WarpPLS 5.0 User Manual, 45. https://doi.org/10.1007/ SpringerReference_28001.

Lee, J. S., \& Hsieh, C. J. 2010. A research in relating entrepreneurship, marketing capability, innovative capability, and sustained competitive advantage. Journal of Business \& Economics Research, 8(9), 109e119.

Lin, S. F., Miao, Q., \& Nie, K. 2012. A case study on entrepreneurship for sustained innovation. African Journal of Business Management, 6(2), 493-500.

Malhotra, N.K. 2010. Marketing Research. An Applied Orientation. Sixth Edition. Person Education.

Miller, K.D. 1993. Industry and country effects on managers' perceptions of environmental uncertainties, Journal of International Business Studies, pp 693-714.

Morgan, N.A., Rebecca, J.S., and Vorhies, D.W. 2009. Linking Marketing Capabilities with Profit Growth, International Journal of Research in Marketing, 26 (4), 284-93

O'Cass, A., and Ngo, L.V. 2011. Winning Through Innovation and Marketing: Lessons from Australia and Vietnam, Industrial Marketing Management, 40 (8), 1319-29.

Onyango, K. 2016. Influence of Digital Marketing Strategies on Performance of Cut flowers Exporting Firms In Kenya. Thesis. School Of Business, University of Nairobi

Padukkage, A., Hooper, V., and Toland, J. 2015. Implications of Environmental Uncertainty for Business-IT Alignment: A Comparative Study of SMEs and Large Organizations. Australasian Conference on Information Systems 2015, Adelaide, Australia

Shane, S. 2003. A general theory of entrepreneurship. The individual opportunity nexus. Cheltenham: Edward Elgar.

Singarimbun, M. dan Effendi, S. 2011. Metode Penelitian Survei. Pustaka LPES 
Sivadas, E., \& Dwyer, F. R. 2000. An Examination of organizational factors influencing new product success in internal and alliance-based processes. Journal of Marketing, 64(1), 31 49.

Sulistyo, H. dan Siyamtinah 2016. Innovation capability of SMEs through entrepreneurship, marketing capability, relational capital, and empowerment. Asia Pacific Management Review. 2016. http://dx.doi.org/10.1016/j.apmrv.2016.02.002

Thornhill, S. 2006. Knowledge, Innovation, and firm performance in high and low technology regimes. Journal of Business Venturing, 21(5), 687-703.

Tsai, M.T., and Tsai, C. L. 2010. Innovation capability and performance in Taiwanese science Parks: Exploring the moderating effects of industrial clusters fabric. The International Journal of Organizational Innovation, 2(4).

Wardaya, A., Sasmoko, So, I.G., Bandur, A. 2019. Mediating Effects of Digital Marketing on Dynamic Capability and Firm Performance: Evidence from Small and Medium-sized Enterprises (SMEs) in Indonesia. International Journal of Recent Technology and Engineering (IJRTE) ISSN: 2277-3878, Volume-8, Issue- 1C2, May 2019

Weerawardena, J. 2003. The role of marketing capability in innovation-based competitive strategy. Journal of Strategic Marketing, 11(1), 15e35.

Wisdom, E. 2015. The impact of e-marketing on business performance: A case study of the Midlands Meander Association members. Thesis. Durban University of Technology

$\mathrm{Xu}, \mathrm{H}$., and Koronios, A. 2005. Understanding Information Quality in E-Business, The Journal of Computer Information Systems (45:2), pp 73-82.

Zahra, S. A., \& Shaker, A. 1991. Predictors and financial outcomes of corporate entrepreneurship: An explorative study. Journal of Business Venturing, 6,259-285 